\title{
Depression of Freezing Point of Fish Muscle during Drying.
}

\author{
Tasae KAWAKAMI
}

(The Imperial Fisheries Institute, Tôkyô)

The determination of the freezing point of dead fish muscle is of importance and of interest both from the theoretical and practical points of view in the cold storage industry. It was shown, on the other hand, by Dr. M. TAUTr ${ }^{1)}$ that the velocity of drying of a fish and its final weight are influenced by the vapour tension of the bodily juice. Hence the determination of the freezing point has also bearings in this connection. Many investigations concerning the freezing point have been made by physiologists with the fresh tissues of various kinds of animals, but there are no experiment reported with the fish muscle in the course of decomposition or of drying.

In the present experiments, the freezing point has been determined by the simple expedient of packing the tissue about the bulb of a Beckmann thermometer contained in the freezing tube of usual cryoscopic apparatus, as used by $\mathrm{S}_{\mathrm{ABBATANI}}{ }^{2}$ ) for the determination of osmotic pressure of tissues. The apparatus used is as shown in Fig. 1, in which $\mathrm{A}$ is the Beckmann thermometer,

$B$ the freezing tube, $C$ the freezing-mixture, ice and

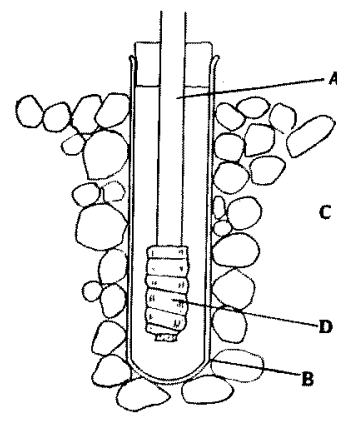

Fig. 1. common salt, and D the sample. The tissue, after it has been super-cooled to a certain degree, suddenly freezes, and the temperature is raised by the heat of freezing and then it is gradually lowered The freezing

c point is thus determined just as in the case of a liquid.

If the second law of RAourt on the depression of freezing point of dilute solution is tenable for the bodily juice, the depression $\theta_{0}$ is proportional to the molar concentration of the bodily juice $c_{0}$. Thus, if $\theta_{0}$ and $c_{0}$ are changed to $\theta$ and $c$ respectively during drying, the following relation holds among those quantities:

$$
\theta=\theta_{0} \frac{c}{c_{0}}
$$

If we assume that the dissolved substances in the bodily juice does not suffer from any change in the course of drying, $c$ is inversely proportional 
to the total quantity of water, which is considered to be uniformly distributed in the fish-muscle. Hence,

$$
\theta=\theta_{0} \frac{\rho_{\theta} V_{0}}{\rho V}
$$

where $\rho$ is the density. of water, $V$ the volume of fish, $\rho_{0}$ and $V_{0}$ being the values in the initial condition. On the other hand, if $\mu$ represents the specific gravity of fish muscle and $\mu_{0}$ its initial value, the total weight of the fish-muscle $W$ can be expressed by

$$
W=\mu V=\rho V+\left(\mu_{0}-\rho_{0}\right) V_{0}
$$

and, in the initial condition, by

$$
W_{0}=\mu_{0} V_{0}
$$

From these equations we get

$$
\frac{W}{W_{0}}=\frac{1}{\mu_{j}}\left\{\rho \frac{V}{V_{0}}+\left(\mu_{0}-\rho_{0}\right)\right\}, \quad \text { or } \quad \frac{V_{0}}{V}=\frac{\rho}{\mu_{0}} \frac{1}{\frac{W}{W_{0}}+\frac{\rho}{\mu_{0}}-1}
$$

Substituting in the equation (1), we get

$$
\theta=\theta_{0} \frac{\rho_{\mathrm{n}}}{\mu_{0}} \frac{1}{\frac{W}{W_{0}}+\frac{\rho_{\mathrm{o}}}{\mu_{0}}-1} .
$$

That is to say, $\theta$ is inversely proportional to $\frac{W}{W_{0}}+\frac{\rho_{0}}{\mu_{0}}-1$.

Experiment 1. An experiment was made to know how the depression

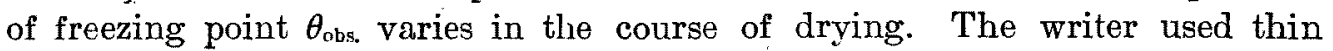
small slices of muscle of carp about $10 \mathrm{~g}$. in weight, which were let to dry slowly at $+3^{\circ} \mathrm{C}$. The weight $W$ and $\theta$ were measured every day. The results of the experiment are summarized in Table 1 . In the calculation of $\theta_{\text {cal. }}$, the writer used the water content which was determined by the usual heating method as the value of $\frac{\rho_{0}}{\mu_{0}} \quad$ Table 1 shows that $\theta_{\text {cal. }}$ does not well coincide with $\theta_{\text {obs., }}$ but in general $\theta_{\text {obs. }}$ shows larger value than that of $\theta_{\mathrm{cal}}$.

The discrepancy seems to be explained, if we assume that there exists in fish such parts of water, which remain unfrozen in the usual process of freezing, just as in the case of freezing of egg white, studied by St. JoHN ${ }^{3)}$ Considering $\frac{\rho_{0}}{\mu_{0}}$ as unknown, we get from the equation (2),

$$
\frac{\rho_{0}}{\mu_{0}}=\frac{\theta}{\theta_{0}-\theta}\left(\frac{W}{W_{0}}-1\right)
$$


Fig. 3 shows the relation between $\theta\left(\frac{W}{W_{0}}-1\right)$ and $\left(\theta_{0}-\theta\right)$. It shows that Table 1.

\begin{tabular}{|c|c|c|c|c|c|}
\hline Sample & $\frac{W}{W_{0}}$ & $\theta_{\text {obs. }}$ & $\theta$ cal. & Moisture & $\frac{\rho_{0}}{\mu_{0}}$ \\
\hline No. 1 & $\begin{array}{l}1.000 \\
0.843 \\
0.693 \\
0.589 \\
0.507\end{array}$ & $\begin{array}{l}0.60 \\
1.02 \\
1.37 \\
1.75 \\
2.27\end{array}$ & $\begin{array}{l}0.60 \\
0.75 \\
0.98 \\
1.25 \\
1.60\end{array}$ & 0.788 & 0.645 \\
\hline No. 2 & $\begin{array}{l}1.000 \\
0.856 \\
0.708 \\
0.616 \\
0.511\end{array}$ & $\begin{array}{l}0.70 \\
0.76 \\
1.05 \\
1.25 \\
2.14\end{array}$ & $\begin{array}{l}0.70 \\
0.85 \\
1.10 \\
1.34 \\
1.78\end{array}$ & 0.804 & 0.756 \\
\hline No. 3 & $\begin{array}{l}1.000 \\
0.810 \\
0.668 \\
0.631 \\
0.539\end{array}$ & $\begin{array}{l}0.67 \\
0.94 \\
1.46 \\
1.58 \\
2.24\end{array}$ & $\begin{array}{l}0.67 \\
0.88 \\
1.16 \\
1.26 \\
1.60\end{array}$ & 0.793 & 0.648 \\
\hline No. 4 & $\begin{array}{l}1.000 \\
0.984 \\
0.961 \\
0.917 \\
0.880 \\
0.814 \\
0.756 \\
0.666\end{array}$ & $\begin{array}{l}0.74 \\
0.84 \\
0.91 \\
0.94 \\
1.01 \\
1.83 \\
1.40 \\
1.90\end{array}$ & $\begin{array}{l}0.74 \\
0.76 \\
0.77 \\
0.82 \\
0.87 \\
0.96 \\
1.06 \\
1.26\end{array}$ & 0.806 & 0.520 \\
\hline
\end{tabular}

$\frac{\rho_{0}}{\mu_{0}}$ are nearly constant, and their values are about 0.63 , while the usual heating method gives $80 \%$ for the water content (moisture).

The amount of ice formed in fish muscles at low temperatures was studied by D. B. FinN $^{4)}$. If we assume that the concentration of remaining bodily juice is the same whether the removal of water is due to freezing or drying, $W_{0}-W$ give the amount of ice produced at $-\theta^{\circ} \mathrm{C}$., since the temperature of freezing muscle must coincide with the freezing point of the remaining bodily juice. The results are given in Fig. 3, showing an agreement with FrNy's results.

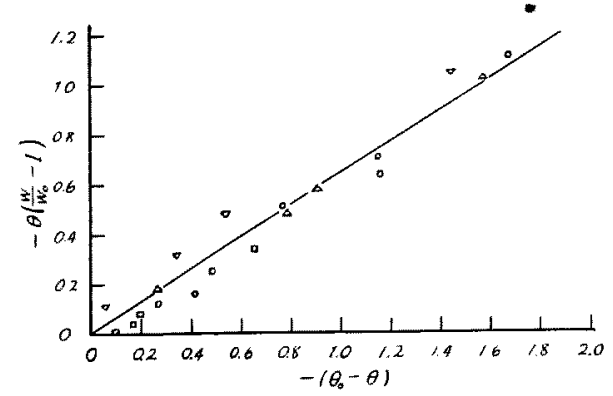

Fig. 2. Fresh muscles. Different marks denote different samples.

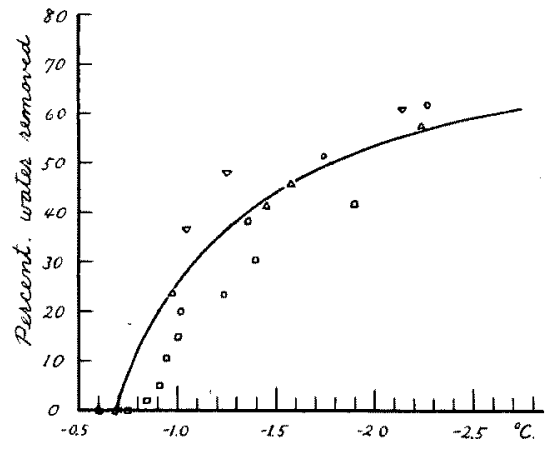

Fig. 3. Fresh carp.

Experiment 2. It is well known fact that during the putrefaction of fish the decomposition of larger molecules of proteins and other substances into smaller ones takes place. It will be natural, therefore, to assume, that the molar concentration of bodily juice is increased and consequently the freez- 
ing point is lowered. For the purpose of verifying this relation, an experiment was made, using freshly killed carp as samples (Table 2). In table 2, $t$ denotes the time of storage of the samples. Samples No. 1 and No. 2 were stored in cold storage, at $3^{\circ} \mathrm{C}$, and Samples No. 3 and No. 4 were stored in a thermostat, regulated at the temperature of $9^{\circ} \mathrm{C}$.

Table 2.

Change of $\theta$ during storage $\left({ }^{\circ} \mathrm{C}\right)$.

\begin{tabular}{|c|c|c|c|c|c|c|c|c|c|c|c|}
\hline$t$ (days) & 0 & 1 & 2 & 3 & 4 & 5 & 6 & 7 & 8 & 9 & 10 \\
\hline No. 1 & 0.60 & .67 & .78 & .82 & .75 & .80 & - & - & - & - & - \\
2 & .70 & .72 & .75 & .74 & .74 & - & - & $\overline{-}$ & $\overline{.78}$ & $\overline{-}$ & $=$ \\
3 & .77 & .72 & $\overline{.73}$ & .71 & .74 & - & $\overline{70}$ & - & - & .71 & .91 \\
\hline
\end{tabular}

Table 3.

\begin{tabular}{|c|c|c|c|}
\hline Sample & $\frac{W}{W_{0}}$ & $\theta$ obs. & Moisture \\
\hline No. 5 & $\begin{array}{l}1.000 \\
0.829 \\
0.729 \\
0.645 \\
0.601\end{array}$ & $\begin{array}{l}0.70 \\
1.03 \\
2.31 \\
2.94 \\
3.87\end{array}$ & 0.802 \\
\hline No. 6 & $\begin{array}{l}1.000 \\
0.940 \\
0.872 \\
0.801 \\
0.740 \\
0.689\end{array}$ & $\begin{array}{l}0.76 \\
1.28 \\
2.22 \\
2.80 \\
2.89 \\
3.41\end{array}$ & 0.800 \\
\hline No. $7^{*}$ & $\begin{array}{l}1.000 \\
0.934 \\
0.889 \\
0.846 \\
0.819 \\
0.792 \\
0.767\end{array}$ & $\begin{array}{l}1.30 \\
1.91 \\
2.17 \\
2.14 \\
3.23 \\
3.14 \\
3.24\end{array}$ & 0.686 \\
\hline No. $8^{*}$ & $\begin{array}{l}1.000 \\
0.917 \\
0.868 \\
0.815 \\
0.780 \\
0.748\end{array}$ & $\begin{array}{l}1.28 \\
2.14 \\
2.46 \\
3.59 \\
3.49 \\
3.67\end{array}$ & 0.686 \\
\hline
\end{tabular}

* Tetrapterus mazara J. \& $\mathbf{S}$.
Table 4.

\begin{tabular}{|c|c|c|c|c|}
\hline Sample & $\frac{W}{W_{0}}$ & $\theta_{\text {obs. }}$ & Moisture & $\frac{\rho_{0}}{\mu_{0}}$ \\
\hline No. 9 & $\begin{array}{l}1.000 \\
0.938 \\
0.841 \\
0.716 \\
0.624 \\
0.553 \\
0.634\end{array}$ & $\begin{array}{l}0.73 \\
0.81 \\
0.9 .2 \\
0.99 \\
1.21 \\
1.59 \\
1.83\end{array}$ & 0.795 & 0.822 \\
\hline No. 10 & $\begin{array}{l}1.000 \\
0.884 \\
0.734 \\
0.680 \\
0.561 \\
0.471 \\
0.411\end{array}$ & $\begin{array}{l}0.70 \\
0.79 \\
0.97 \\
1.24 \\
1.67 \\
2.38 \\
2.94\end{array}$ & 0.795 & 0.765 \\
\hline No. 11 & $\begin{array}{l}1.000 \\
0.837 \\
0.719 \\
0.604 \\
0.493 \\
0.428\end{array}$ & $\begin{array}{l}0.80 \\
0.97 \\
1.31 \\
1.63 \\
2.18 \\
2.98\end{array}$ & 0.800 & 0.789 \\
\hline No. 12 & $\begin{array}{l}1.000 \\
0.891 \\
0.862 \\
0.622 \\
0.558 \\
0.482\end{array}$ & $\begin{array}{l}0.84 \\
1.04 \\
1.32 \\
1.71 \\
2.03 \\
3.08\end{array}$ & 0.800 & 0.672 \\
\hline
\end{tabular}

As shown in the table, though the accuracy of the experiment is not high, it is understood that there is but slight evidence of lowering of freezing point, so far as the water content is left unchanged. 
Experiment 3. To examine whether the relation between $\theta\left(\frac{W}{W_{0}}-1\right)$ and $\theta_{0}-\theta$ is influenced or not by the decomposition, the author made two series of similar experiments, one with the carp (Samples No. 5 and No. 6), which were stored in a thermostat at $9^{\circ} \mathrm{C}$. for 5 and 9 days, and the other with Tetrapterus mazara Jordan \& Snyder (Sample No. 7 and No. 8), which was bought from the market, with the results, as summarized in Table 3 . In this case, the relation is not linear as shown in Fig. 4. Evidently, however, $\theta$ giving an assigned value of $\frac{W}{W_{0}}$ is greater for the stored muscle than that for fresh muscle.

Experiment 4. The carp, which were stored in a thermostat at $10^{\circ} \mathrm{C}$, for 2 to 6

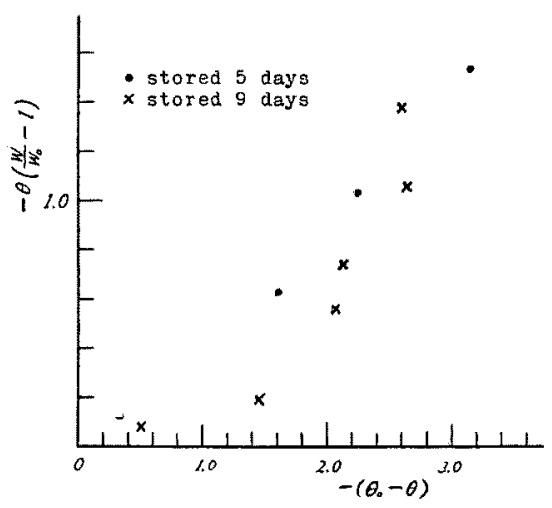

Fig. 4. Stored carp. days, were made to dry in frozen state at about $-3^{\circ} \mathrm{C}$. In this case the relation between $\theta\left(\frac{W}{W_{0}}-1\right)$ and $\left(\theta_{0}-\theta\right)$ becomes linear, while the value of $\frac{\rho_{0}}{\mu_{0}}$ given by the equation (3), evidently diminishes according to the period of storage, as shown in Table 4 .

\section{Sammary}

1. The depression of freezing point $\theta$ of carp muscle, which is dried to $\frac{W}{W_{0}}$ of the original weight, is given by the equation, $\theta=\theta_{0} \frac{\rho_{0}}{\mu_{0}}\left(\frac{W}{W_{0}}+\frac{\rho_{0}}{\mu_{0}}-1\right)^{-1}$, where $\theta_{0}$ is original depression, though the constant $\frac{\rho_{0}}{\mu_{0}}$ in the equation is generally smaller than the water content determined by heating method.

2. For the stored muscle, the relation between $\theta\left(\frac{W}{W_{0}}-1\right)$ and $\left(\theta_{0}-\theta\right)$ is not linear, when the muscle is dried in unfrozen state, but still linear, when dried in frozen state. In both cases, the longer the muscle is stored before drying, the greater the depression becomes.

The writer wishes to express herewith his hearty thanks to $\mathrm{Mr}$. $\mathrm{M}$. Okada for the constant guidance and also to Prof. M. Tauti and Prof. $T$. Oya for the valuable advices rendered to him.

\section{Literature}

1) Tauti, M. : J. Imper. Fish. Inst, 23 (1), 1927, 2.

2) Sabbatani: Arch. ital. Biol., 36, 1901, 440.

3) St. Jorn, J.L.: J. Amer. Chem. Soc., 53, $1931,4014$.

4) Finn, D.B.: Contr. Canad. Biol. Fish., New Ser., $8(21 \sim 26)$, 1934, 311 330. 